\title{
Pendampingan Desain Layanan Madrasah berbasis Website pada YPI Nahdlotusy Syubban
}

\author{
Edi Daenuri Anwar \\ Universitas Islam Negeri Walisongo Semarang \\ Email : daenurianwar@walisongo.ac.id
}

\begin{abstract}
Community service has been done to the subject YPI Nahdlotusy Syubban Sarimulyo Winong. This foundation oversee its four units of education; TPQ / Madin, RA, MI and MTs. The approach on this research is partipatory action research/PAR. The focus in this community service is designing website to all unit if servicesof madrasah atYPINahdlotusy Syubban.With the approach of PAR it is expected the participants cooperate to make changes, to solve the existing problems. The Research is divided into three stages, mapping, acting and evaluatiing. The results of mapping been succeeded by sharing between researchers, the head of TPQ/ Madin, RA, MI and MTs and the head of Yayasan foundation. Finally website service with name www.yapinasya-pati.sch.id succesfully formed. The next stage is conducting workshop with the expert of designing web. The participants are the head of all each unit, admin of any units and several teachers. The output of this workshop is all participants have proficient in the management of the web.
\end{abstract}

Abstrak: Pengabdian dengan subjek Yayasan Pendidikan Islam (YPI) Nahdlotusy Syubban Sarimulyo Winong Pati telah terlaksana. Yayasan ini menaungi empat unit pendidikan yaitu TPQ/Madin, RA, MI dan MTs. Pendekatan yang digunakan dalam pengabdian ini yaitu PAR ( partipatory action research). Fokus dampingan dalam pengabdian ini adalah desain website untuk layanan madrasah dari unit-unit YPI Nahdlotusy Syubban. Dengan pendekatan PAR diharapkan Subjek dampingan melakukan perubahan untuk memecahkan solusi dari problem yang ada. Pengabdian ini terbagi menjadi 3 tahap yaitu mapping lokasi, tindakan dan evaluasi. Hasil mapping lokasi yang dilanjutkan melalui sharing antara peneliti, kepala sekolah setiap unit YPI Nahdlotusy Syubban meliputi TPQ/Madin, RA, MI dan MTs beserta pengurus yayasan. Akhirnya diusulkan dibentuklah website layanan dengan nama www.yapinasya-pati.sch.id sebagai web layanan madrasah.Kemudian dilanjutkan tindakan berupa workshop dengan narasumber ahli desain web dan peserta masing kepala masing-masing unit, admin dari setiap unit dan beberapa guru. Output workshop berupa admin website dari masing-masing unit sudah mahir dalam manajemen web.

Kata Kunci: madrasah, website, layanan. 


\section{PENDAHULUAN}

Kabupaten Pati merupakan Kabupaten di Jawa Tengan dengan lokasi di Pantai Utara Jawa (Pantura). Dengan keadaan geografi yang secara umum panas, dan keadaan ekonomi yang secara umum terbagi menjadi 3 yaitu daerah yaitu pantai kebanyakan adalah nelayan, daerah dataran tinggi kebanyakan petani tegal dan dataran rendah yang sebagian penduduknya bertani dengan sistem tadah hujan yang secara ekonomi yang kurang menguntungkan. Desa Sarimulyo merupakan lokasi dari Madrasah Nahdlotusy Syubban merupakan dataran rendah, sehingga sebagian besar masyarakatnya menggantungkan perekonomiannya pada pertanian. Pertanian dengan tadah hujan yang tidak menentu ini mendorong masyarakat mencari penghidupan yang lebih layak, sehingga menyebabkan kebanyakan masyarakat menjadi perantau baik dalam negeri maupun luar negeri (Hongkong, korea, malaysia, brunai, dan jepang). Faktor inilah yang menyebabkan masyarakat yang masih tinggal para perempuan dan usia tidak produktif (Anwar, E.D. dkk, 2015)

Pendirian Madrasah ini berawal dari kondisi usia sekolah yang pada tahun tahun 1965-an masyarakat ketika itu sekolah harus berjalan kaki sekitar $2 \mathrm{~km}$. Yang menyedihkan bahwa masyarakat yang bisa sekolah hanyalah mereka yang terpandang dan mampu, sedangkan yang ekonomi menengah kebawah harus menelan pil pahit untuk tidak sekolah. Sehingga tergeraklah hati seorang Dermawan untuk mewakafkan tanahnya seluas $1.935 \mathrm{~m}^{2}$ untuk dijadikan Madrasah dan telah di aktenotariskan pada tahun 1991. Sejak tahun 1968 sampai sekarang pasang surut pendidikan mulai terasa. Pada awal-awal berdiri jumlah murid sangat banyak sekali sampai 30 - 40 siswa sampai tahun 2000 an masih terasa banyak tetapi setelah tahun 2000 jumlah murid semakin berkurang karena ada beberapa kendala geografi yang kurang menguntungkan yaitu karena jumlah murid yang hanya ditopang oleh satu dusun/dukuh dari desa gendoan, berhasilnya program KB dan manajemen sekolah yang kurang baik. (Anwar. E.D .dkk, 2015)

Disamping masalah tersebut sebenarnya keberadaan madrasah merupakan bagian yang tidak terpisahkan dalam status pendidikan sebagaimana termaktub dalam sisdiknas (UU No.2 Tahun 1989) sedangkan berdasarkan peraturan pemerintah No. 28 dan 29 serta di ikuti oleh surat keputusan menteri pendidikan dan Kebudayaan dan Menteri Agama dengan jelas bahwa madrasah adalah sekolah yang berciri khas agama islam. Sehingga Madrasah yang merupakan salah satu jenjang pendidikan berciri khas agama Islam.

Keberadaan Madrasah (Anwar. E.D. dkk, 2015) memiliki beban yang sama dalam status, tugas dan tanggung jawabnya dengan sekolah umum dalam 
mencerdaskan kehidupan bangsa. Ditambah dengan nilai lebih ciri khas agama islam yang menjadi beban dan tanggung jawabnya dalam berbagai proses pendidikan. Namun keberadaannya memang biasanya sangat berbeda dalam pembiayaan, sarana prasarana dan kulitas mutu pendidikan.

Yayasan Pendidikan Islam (YPI) Nahdlotusy Syubban adalah sebuah yayasan nirlaba sosial keagamaan yang bergerak dalam bidang dakwah dan pendidikan Islam. Yayasan ini membawahi beberapa unit pendidikan dari Madin/TPQ, Raudhatul Athfal (RA), Madrasah Ibtidaiyyah (MI) dan Madrasah Tsanawiyyah (MTs). Madrasah yang dinaunginya oleh YPI Nahdlotusy Syubban yaitu MI dan MTs Nahdlotusy Syubban memiliki Pola layanan masih manual sehingga bersifat lambat, atau bahkan ada informasi yang tidak tersampaikan kepada publik.

Kondisi layanan ini membuat kecepatan informasi tidak terkomunikasikan dengan baik, disamping hampir semua layanan administrasi pendidikan kepada dinas terkait menggunakan online. Demikian juga kesulian dalam penyampaian informasi yang diberikan oleh madrasah kepada calon siswa atau wali siswa tentang madrasah. Faktor inilah yang menjadi domain bagi panitia penerimaan siswa baru akan kekurangan murid dalam penerimaan siswa baru.

Berdasarkan masalah-masalah tersebut, maka diperlukan suatu sistem manajemen layanan berbasis web yang dapat digunakan untuk mempermudah layanan, administrasi, pengelolann, informasi seluruh civitas akademika yayasan dan madrasah. Maka peneliti melakukan kegiatan pendampingan yang berjudul “ Pendampingan Desain Layanan Madrasah Berbasis Website pada YPI Nahdlotusy Syubban Untuk Meningkatkan Layanan, Brand dan Mutu Madrasah"

Adapun permasalahan yang timbul adalah bagaimana tindakan pendampingan Desain Layanan Madrasah berbasis Website pada YPI Nahdlotusy Syubban untuk meningkatkan layanan, Brand dan Mutu Madrasah. Untuk menghindari meluasnya masalah maka rumusan masalah dalam penelituian ini dibatasi pada, pertama, Bagaimana sistem pendampingan desain web dinamis untuk keperluan manajemen madrasah yang memiliki fungsi: sebagai sarana informasi, sebagai sarana Layanan berbasis madrasah dan sebagai sarana Promosi madrasah. Kedua, Bagaimana terwujudnya website madrasah yang dapat meningkatakn Layanan, Brand dan mutu madrasah yang berkesinambungan. 


\section{KAJIAN TEORITIS MADRASAH DAN PENGEMBANGAN WEB}

Beberapa definisi terkait subyek dampingan perlu diperjelas untuk mendapatkan gambaran utuh keberadannya. Misalnya definisi madrasaha sebagai lembaga pendidikan. Lembaga menurut kbbi.web.id adalah bakal dari sesuatu, asal mula yang akan menjadi sesuatu, bakal, bentuk, wujud, rupa, acuan, ikatan, badan atau organisasi yang mempunyai tujuan jelas terutama dalam bidang keilmuan. Sedangkan menurut ensiklopedi Indonesia, lembaga pendidikan yaitu suatu wadah pendidikan yang dikelola demi mencapai hasil pendidikan yang diinginkan. (https://kbbi.web.id/lembaga).

Di era modern, setipa lembaga bersentuhan dengan sistem informasi. Sistem informasi dalam suatu organisasi dapat dikatakan sebagai suatu sistem yang menyediakan informasi bagi semua tingkatan dalam organisasi tersebut kapan saja diperlukan. Sistem ini menyimpan, mengambil, mengubah, mengolah dan mengkomunikasikan informasi yang diterima dengan menggunakan sistem informasi atau peralatan sistem lainnya. Menurut Kristianingsih, Sisteminformasi akademik adalah sistem yangmemberikan layanan informasi yang berupadata dalam hal ini yang berhubungan denganakademik.

Komponen-komponen dari sistem informasi terdiri atas komponen input, komponen model, komponen output, komponen teknologi, komponen hardware, komponen software, komponen basis data, dan komponen kontrol (Ruwandar, dkk, 2012). Semua komponen tersebut saling berinteraksi satu dengan yang lain membentuk suatu kesatuan untuk mencapai sasaran. Elemenelemen dari sistem informasi berupa orang, prosedur, perangkat keras, perangkat lunak, basis data, jaringan komputer dan komunikasi data. Semua elemen ini merupakan komponen fisik.

Web server adalah merupakan software yang memberikan layanan data yang berfungsi menerima permintaan HTTP atau HTTPS dari klien yang dikenal dengan browser web dan mengirimkan kembali hasilnya dalam bentuk halamanhalaman web yang umumnya berbentuk dokumen HTML. Fungsi utama sebuah server web adalah untuk mentransfer berkas atas permintaan pengguna melalui protokol komunikasi yang telah ditentukan. Sebuah halaman web dapat terdiri atas berkas teks, gambar, video, dan lainnya. Server HTTP Apache atau Server Web/WWW Apache adalah server web yang dapat dijalankan di banyak sistem operasi (Unix, BSD, Linux, Microsoft Windows dan Novell Netware serta platform lainnya) yang berguna untuk melayani dan memfungsikan situs web. Protokol yang digunakan untuk melayani fasilitas web/www ini menggunakan HTTP (Iswanto,2007). 
Database (Basis Data) adalah sebuah koleksi dari data yang saling berelasi, di mana data tersebut disimpan pada komputer sedemikian hingga sebuah program komputer dapat berinteraksi dan menggunakan data yang disimpan tersebut untuk menyelesaikan masalah ataupun menjawab pertanyaan. Data didalam database perlu diorganisasikan sedemikian rupa sehingga informasi yang terkandung di dalamnya mudah diakses. Databases yang digunakan dalam penelitian ini adalah MySQL. MySQL adalah sebuah perangkat lunak sistem manajemen basis data SQL (bahasa Inggris: database management system) atau DBMS yang multithread, multi-user, dengan sekitar 6 juta instalasi di seluruh dunia. MySQL adalah Open source sistem manajemen database SQL yang paling popular, dikembangkan, didistribusikan, dan didukung oleh Oracle Corporation. Website MySQL menyediakan informasi terbaru tentang software MySQL (Kadir, 2010; Ruwandar, dkk, 2012).

PHP merupakan sebuah bahasa script server-side yang bisa digunakan dengan bahasa HTML atau dokumennya secara bersamaan untuk membangun sebuah aplikasi di web yang sangat banyak kegunaannya. PHP merupakan bahasa yang disertakan dalam dokumen HTML, bekerja di sisi server side HTML embedded scripting. Artinya sintaks dan perintah yang diberikan sepenuhnya dijalankan di server tetapi disertakan pada halaman HTML biasa, sehingga script-nya tidak tampak di sisi klien (Solichin,2010).

JavaScript adalah bahasa skrip yang populer di internet dan dapat bekerja di sebagian besar penjelajah web populer seperti Internet Explorer (IE), Mozilla Firefox, Netscape dan Opera. Kode JavaScript dapat disisipkan dalam halaman web menggunakan tag SCRIPT.Javascript adalah sebuah bahasa komputer atau kode pemrograman yang digunakan pada website agar website tersebut menjadi lebih interaktif dan dinamis. Penggunaan kode javascript pada sebuah website bersifat opsional, artinya tidak harus selalu ada. Namun, website-website maupun blog modern saat ini hampir semuanya menggunakan kode javascript walaupun sedikit (www.syakirurohman.net/2014 diakses tanggal 21 Maret 2016).

Website adalah kumpulan halaman-halaman yang digunakan untuk menampilkan informasi teks, gambar diam atau gerak, animasi, suara, dan atau gabungan baik yang bersifat statis maupun dinamis yang saling terkait dimana masing-masing dihubungkan dengan jaringan-jaringan halaman (hyperlink). Unsur-unsur website atau situs. Untuk menyediakan keberadaan sebuah website, maka harus tersedia unsur-unsur penunjangnya. Pertama, Nama domain (Domain name/URL - Uniform Resource Locator). Nama domain/ Domain Name/ URL adalah alamat unik di dunia internet yang digunakan untuk mengidentifikasi sebuah website, atau dengan kata lain domain name adalah 
alamat yang digunakan untuk menemukan sebuah website pada dunia internet. Contoh :http://www.google.com. http://www.walisongo.ac.id.

Nama domain diperjualbelikan secara bebas di internet dengan status sewa tahunan. Nama domain sendiri mempunyai identifikasi ekstensi/akhiran sesuai dengan kepentingan dan lokasi keberadaan website tersebut. Contoh nama domain ber-ekstensi internasional adalah com, net, org, info, biz, name, ws. Contoh nama domain ber-ekstensi lokasi Negara Indonesia adalah co.id (untuk nama domain website perusahaan), ac.id (nama domain website perguruan tinggi), go.id (nama domain website instansi pemerintah), or.id (nama domain website organisasi), sch.id (nama domain website organisasi).

Kedua, Rumah tempat website (Web hosting). Pengertian Web Hosting adalah ruangan yang terdapat dalam harddisk tempat menyimpan berbagai data, file-file, gambar dan lain sebagainya yang akan ditampilkan di website. Besarnya data yang bisa dimasukkan tergantung dari besarnya web hosting yang disewa, semakin besar web hosting semakin besar pula data yang dapat dimasukkan dan ditampilkan dalam website. Web Hosting juga diperoleh dengan menyewa. Besarnya hosting ditentukan ruangan harddisk dengan ukuran MB(Mega Byte) atau GB(Giga Byte). Lama penyewaan web hosting rata-rata per tahun.

Ketiga, Bahasa Program (Scripts Program). Scripts Program adalah bahasa yang digunakan untuk menerjemahkan setiap perintah dalam website yang pada saat diakses. Jenis bahasa program sangat menentukan statis, dinamis atau interaktifnya sebuah website. Semakin banyak ragam bahasa program yang digunakan maka akan terlihat website semakin dinamis, dan interaktif serta terlihat bagus.

Beragam bahasa program saat ini telah hadir untuk mendukung kualitas website. Jenis jenis bahasa program yang banyak dipakai para desainer website antara lain HTML, ASP, PHP, JSP, Java Scripts, Java applets dsb. Bahasa dasar yang dipakai setiap situs adalah HTML sedangkan PHP, ASP, JSP dan lainnya merupakan bahasa pendukung yang bertindak sebagai pengatur dinamis, dan interaktifnya situs.Bahasa program ASP, PHP, JSP atau lainnya bisa dibuat sendiri. Bahasa program ini biasanya digunakan untuk membangun portal berita, artikel, forum diskusi, buku tamu, anggota organisasi, email, mailing list dan lain sebagainya yang memerlukan update setiap saat.

Keempat, Desain website. Desain website menentukan kualitas dan keindahan sebuah website. Desain sangat berpengaruh kepada penilaian pengunjung akan bagus tidaknya sebuah website. Saat ini sangat banyak jasa web designer, terutama di kota-kota besar. Perlu diketahui bahwa kualitas situs sangat ditentukan oleh kualitas designer. Semakin banyak penguasaan web designer 
tentang beragam program/software pendukung pembuatan situs maka akan dihasilkan situs yang semakin berkualitas, demikian pula sebaliknya.

Keilma, Publikasi website. Publikasi web berfungsi untuk mengenalkan situs kepada masyarakat. Hal tersebut memerlukan publikasi/ promosi. Cara yang biasanya dilakukan dan paling efektif dengan tak terbatas ruang atau waktu adalah publikasi langsung di internet melalui search engine-search engine (mesin pencari, spt : Yahoo, Google, Search Indonesia, dsb) Cara publikasi di search engine ada yang gratis dan ada pula yang membayar. Yang gratis biasanya terbatas dan cukup lama untuk bisa masuk dan dikenali di search engine terkenal seperti Yahoo atau Google. Cara yang efektif untuk pemasaran sebuah web hosting dengan publikasi berbayar, walaupun harus sedikit mengeluarkan akan tetapi situs cepat masuk ke search engine dan dikenal oleh pengunjung (https://www.boc.web.id/pengertian-website-webhostingdomainname/).

\section{METODE PENDAMPINGAN}

Pengabdian yang dilakukan oleh pengabdi pada penelitian "Pendampingan Desain Layanan Madrasah Berbasis Website pada YPI Nahdlotusy Syubban untuk Meningkatkan Layanan, Brand dan Mutu Madrasah" ini merupakan penelitian Participatory Action Research (PAR). Pada dasarnya PAR adalah penelitian yang melibatkan semua pihak yang relevan dalam meneliti secara aktif bersama-sama tindakan saat ini (yang mereka alami sebagai bermasalah) dalam rangka untuk mengubah dan memperbaikinya. Subjek Dampingan melakukan tindakan dengan merenungkan secara kritis historis, politik, budaya, ekonomi, geografis dan konteks lainnya yang dapat di pahami. Participatory action research diharapkan akan diikuti oleh suatu tindakan. Hal ini adalah tindakan yang harus diteliti, diubah dan kemudian diteliti kembali, dalam proses penelitian yang di lakukan oleh para peserta sebagai subyek dampingan. Kerangka tindakan pendampingan ini sesuai dengan diagram alir pada gambar 1.

PAR adalah penelitian dual shift dengan melakukan dua langkah yaitu : pertama, merubah cara berfikir kita tentang penelitian menjadikan penelitian sebuah proses. Hal ini memberikan bahwa hasil penelitian tergantung proses sehingga tidak kaku. Dalam penelitian ini subjek dampingan berperan utuh sebagai pelaku, Guru dan seluruh civitas akademika yayasan pendidikan islam Nahdlotusy Syubban. Mereka berpartisipasi dalam rancangan, implementasi, dan eksekusi penelitian. Civitas akademika yayasan dan seluruh guru berpartisipasi dalam rancangan dan implementasi dalam rencana tindak strategis didasarkan pada hasil penelitian. 


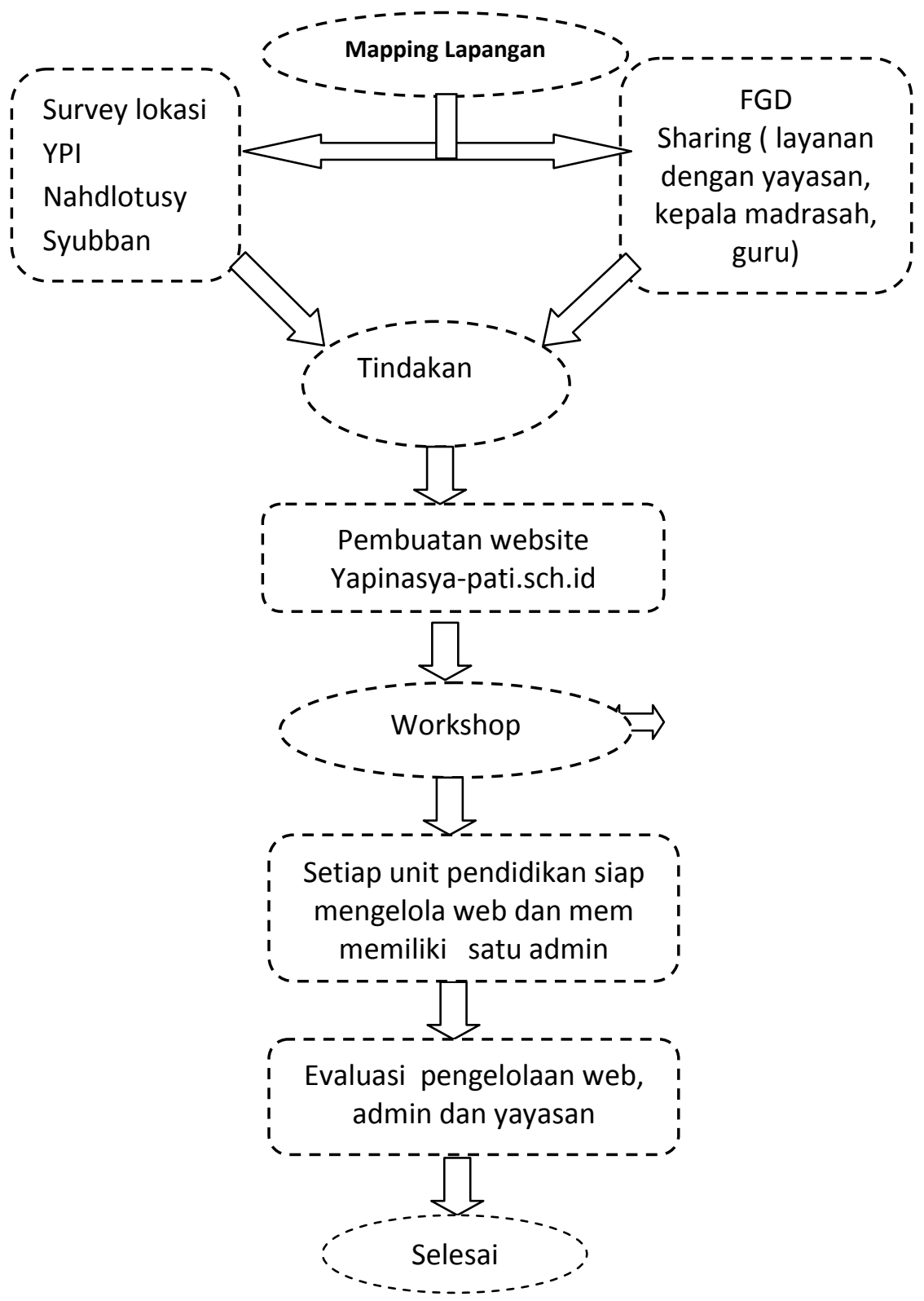

Gb. 1 Diagram alir tindakan operasional

Kedua, PAR(Participation Action Research) adalah proses dimana komunitas sebagai subyek dampingan berusaha mempelajari masalah secara ilmiah dalam 
rangka memandu, memperbaiki, dan mengevaluasi keputusan dan aksi mereka. Sehingga dalam penelitian ini memberikan pengalaman hidup nyata, mimpi, pikiran, kebutuhan, kemauan dari anggota komunitas. Sehingga dalam penelitian ini peneliti bukan berkedudukan sebagai expert tetapi sebagai fasilitator sehingga subjek dampingan memiliki kebebasan untuk menetukan hasil akhir Penelitian.

Guru berpartisipasi dalam rancangan dan implementasi dalam rencana tindak strategis didasarkan pada hasil penelitian. Kedua, PAR(Participation Action Research) adalah proses dimana komunitas sebagai subyek dampingan berusaha mempelajari masalah secara ilmiah dalam rangka memandu, memperbaiki, dan mengevaluasi keputusan dan aksi mereka. Sehingga dalam penelitian ini memberikan pengalaman hidup nyata, mimpi, pikiran, kebutuhan, kemauan dari anggota komunitas. Sehingga dalam penelitian ini peneliti bukan berkedudukan sebagai expert tetapi sebagai fasilitator sehingga subjek dampingan memiliki kebebasan untuk menetukan hasil akhir Penelitian.

Untuk menerapkan metode-metode dalam penelitian PAR ini maka peneliti menempatkan yayasan pendidikan islam nahdlotusy syubban dan seluruh guruguru di unit pendidikan nahdlotusy syubban sebagai subjek dampingan. Subjek dampingan yang dimaksud mereka sebagai pelaku yang merancang, mengimplementasikan dan hasil akhir penelitian. Adapun langkah-langkah yang dilakukan antara lain yaitu. pertama yang dilakukan peneliti adalah dengan melakukan mapping kepada seluruh Guru dan Dewan Yayasan Nahdlotusy Syubban yang bertempat di Rt 03 Rw 04 Kecamatan Winong Kabupaten Pati dengan tujuan Penelitian yang bersifat kolaboratif dengan masyarakat yang menjadi objek penelitian.

Potensi sekolah yang memungkinkan bisa dikembangkan dan di tingkatkan lebih jauh sehingga sekolah yang menjadi objek dampingan menjadi lebih baik. Dalam tindakan kali ini sekaligus melibatkan masyarakat secara umum mengenai kemungkinan-kemungkinan peran serta masyarakat dalam pengembangan sekolah. Sekaligus mengetahui potensi-potensi masyarakat terhadap peningkatan mutu sekolah.

Langkah selanjutnya dengan diskusi- diskusi dan wawancara madrasah dan masyarakat yang bertujuan untuk mengetahui keinginan-keinginan dan harapanharapan serta impian madrasah dan keinginan masyarakat terhadap sekolah. Tahap ini untuk mengetahui keinginan dan harapan jangka pendek dan juga jangka panjang. Langkah-langkah tersebut nantinya diharapkan tertuang dalam visi misi dan standar mutu madrasah. 
Setelah mengetahui potensi dan harapan madrasah, maka tindakan yang tidak kalah pentingnya adalah mengetahui kondisi keadaan sekarang, kondisi yang ada, yang dijadikan pijakan pola tindakan bagi kemajuan ke depan. Setelah merangkum dan melakukan pemetaan tentang potensi, impian-impian, kemampuan dan masalah maka selanjutnya di analisis yang meliputi kekuatan, kelemahan, peluang dan ancaman dengan metode SWOT. Menganisis ini akhirnya disusunlah berbagai FGD-FGD dan workshop yang bertujuan untuk menjawab kebutuhan madrasah dalam bentuk website.

Penelitian ini dilaksanakan selama 4 bulan dari bulan juni sampai oktober 2017. Dari mapping lokasi, dilanjutkan dengan sharing, dilanjutkan Focus discussion group (FGD), workshop dan evaluasi Hasil. Sedangkan tempat pengabdian di yayasan Pendidikan Islam Nahdlotusy Syubban yang memiliki empat unit pendidikan dari Taman Pendidikan Al-Quran (TPQ), raudhatul Athfal (RA), Madrasah Ibtidaiyyah (MI) dan Madrasah Tsanawiyyah (MTs). Yayasan Pendidikan Nahdlotusy Syubban tersebut berlokasi di RT 3 RW 4 Desa Sarimulyo Kecamatan Winong Kabupaten Pati.

Metode pengumpulan data pada penelitian ini menggunakan diskusi, sharing dan wawancara. Diskusi dan sharing yang peneliti lakukan diskusi dengan perwakilan dari pihak yayasan, Madrasah Tsanawiyah, Madrasah Ibtidaiyah, Raudlatul Atfal, dan TPQ.

Metode PAR (Participatory Action Research) adalah penelitian yang melibatkan semua pihak yang relevan dalam meneliti secara aktif bersama-sama tindakan saat ini (yang mereka alami sebagai masalah) dalam rangka untuk mengubah dan memperbaikinya. Dengan metode PAR ini subjek dampingan di dampingi, dibantu dan di bimbing untuk bersama-sama untuk menilai, mengukur, mengetahui kondisi sebenarnya tentang kondisi dampingan serta solusi apa yang sebenarnya harus dilakukan untuk memecahkan masalah yang di alami. Sehingga secara mandiri subjek dampingan mencoba memecahkan masalahnya sendiri secara mandiri, sehingga di harapkan setelah selesai dampingan subjek dampingan menjadi mandiri dan berdaya guna dalam mengelola website serta mampu mengembangkan

Data yang di dapatkan dari penelitian PAR ini dari pengumpulan data dan tahap validasi atau matching stage dan tahap selanjutnya adalah pengambilan keputusan. Data penelitian partisipatif action researh ini pemenuhan data dalam rangka penentuan strategi meliputi kelemahan dan kekuatan yang berkaitan dengan Yayasan dan Madrasah.

Tahap selanjutnya adalah tahap penentuan strategi yang di gunakan dalam pembuatan website Nahdlotusy Syubban untuk mengkombinasikan data internal 
(kekuatan dan kelemahan ) dan data eksternal ( peluang dan ancaman) pada lingkungan organisasi. Pada tahap ini sehingga mengambil kesimpulankesimpulan berdasarkan 4 faktor diatas dengan metode analisa yang disebut Analisis SWOT.

Pertama, Strategi Kekuatan -Peluang (S-O atau Maxi-maxi). Strategi yang dihasilkan pada kombinasi ini adalah memanfaatkan kekuatan atas peluang yang telah diidentifikasi. Apabila kekuatan Madrasah adalah pada keunggulan yang keberadaanya dan kebutuhannya telah diidentifikasi pada analisis kesempatan/ peluang.

Kedua, Strategi Kelemahan-Kesempatan (W- O atau Mini-maxi). Kesempatan yang telah diidentifikasi tidak mungkin dimanfaatkan karena kelemahan madrasah. Misalnya peluang calon dari peserta didik tersebut tidak dipunyai oleh perusahaan. Salah satu strategi yang website yang berisi semua informasi madrasah.

Ketiga, Strategi Kekuatan-Ancaman (S atau $\mathrm{T}$ atau Maxi-min). Dalam analisa ancaman ditemukan kebutuhan untuk mengatasinya. Strategi ini mencoba mencari kekuatan-kekuatan yang dimiliki madrasah yang dapat mengurangi atau menangkal ancaman tersebut. Bahaya website di minamalisir oleh admin. Desain dan isi web sesuai dengan permiantaan masyarakat dan stake holders.

Keempat, Strategi Kelemahan-Ancaman (W dan T atau Mini-mini). Strategi untuk meminimalkan kelemahan agar terhindar dari ancaman eksternal. Dalam situasi menghadapi ancaman dan sekaligus kelemahan intern, strategi yang umumnya dilakukan adalah "keluar" dari situasi yang terjepit tersebut. Keputusan yang diambil adalah "mencairkan" sumber daya yang terikat pada situasi yang mengancam tersebut. Cara tersebut bisa dengan membuka ruang dialog dalam web dengan kolom masukan, kritik dan saran dari alumni dan pengguna.

\section{HASIL PENDAMPINGAN}

Kabupaten Pati merupakan Kabupaten di Jawa tengah dengan lokasi di Pantai Utara Jawa (Pantura). Dengan keadaan geografi yang secara umum panas, dan keadaan ekonomi yang secara umum terbagi menjadi 3 yaitu daerah yaitu pantai kebanyakan adalah nelayan, daerah dataran tinggi kebanyakan petani tegal dan dataran rendah yang sebagian penduduknya bertani dengan sistem tadah hujan yang secara ekonomi yang kurang menguntungkan. Desa Sarimulyo merupakan lokasi dari MI Nahdlotusy Syubban merupakan dataran rendah, 
sehingga sebagian besar masyarakatnya menggantungkan perekonomiannya pada pertanian.

Pertanian dengan tadah hujan yang tidak menentu ini mendorong masyarakat mencari penghidupan yang lebih layak, sehingga menyebabkan kebanyakan masyarakat menjadi perantau baik dalam negeri maupun luar negeri (Hongkong, korea, malaysia, brunai, dan jepang). Faktor inilah yang menyebabkan masyarakat yang masih tinggal para perempuan dan usia tidak produktif.

Pendirian sekolah ini berawal dari kondisi usia sekolah yang pada tahun 65an masyarakat ketika itu sekolah harus berjalan kaki sekitar $2 \mathrm{Km}$. Yang menyedihkan bahwa masyarakat yang bisa sekolah hanyalah mereka yang terpandang dan mampu, sedangkan yang ekonomi menengah kebawah harus menelan pil pahit untuk tidak sekolah. Sehingga tergeraklah hati seorang Dermawan untuk mewakafkan tanahnya seluas $1.935 \mathrm{~m} 2$ untuk dijadikan Madrasah dan telah di aktenotariskan pada tahun 1991. Sejak tahun 1968 sampai sekarang pasang surut pendidikan mulai terasa. Pada awal-awal berdiri jumlah murid sangat banyak sekali sampai 30 - 40 siswa sampai tahun 2000 an masih terasa banyak tetapi setelah tahun 2000 peningkatan jumlah murid semakin berkurang karena ada beberapa kendala yaitu geografi yang kurang menguntungkan karena jumlah murid yang hanya ditopang oleh satu dusun/dukuh dari desa gendoan, berhasilnya program KB dan manajemen sekolah yang kurang baik (Anwar. E.D. dkk, 2015).

Kondisi yayasan Nahdlotusy Syubban yang menaungi empat unit pendidikan pada dasarnya adalah adalah lembaga sosial kemasyarakatan yang focus dalam pendidikan islam. Yayasan ini berdiri sebelum era 80-an sedangkan unit pendidikan TPQ baru berdiri tahun 2014. Pola layanan pendidikan ini masih manual menggunakan papan tulis dalam setiap informasi yang diberikan oleh madrasah dan juga dari mulut ke mulut dan juga tulis ( surat khusus kepada orang tua).

Tingkat ekonomi orang tua sangat beranggam ada yang petani, perantauan baik dalam negeri misalnya Jakarta, sumatera, riau dan beberapa kota di Indonesia maupun luar Negeri seperti Hongkong, Malaysia, Brunei Darussalam, Arab Saudi, Korea dan Jepang. Tingkat ekonomi masyarakat juga dipengaruhi dengan tingkat pendidikan yang beragam ada yang SD, SMP maupun SMA dan ada juga sebagian yang Perguruan tinggi. Namun dengan tingkat perkembangan teknologi yang semakin meningkat maka hampir semua orangtua sekarang memiliki HP/ gadget. Kondisi adalah kekuatan yang bisa dimanfaatkan dalam kondisi sekarang. Kemudahan wali murid dan siswa dalam mengakses informasi 
menjadikan peluang yang sangat baik untuk menciptakan layanan yang baik. Bahkan beberapa orang tua wali memberikan gadget kepada anaknya yang berstatus siswa madrasah ibtidaiyyah walaupun hal tersebut harus dibatasi penggunaanya.

Pada prinsipnya dengan dampingan ini diharapkan tercipta sebuah website sebagai basis data dan layanan bagi stakeholder. Sehingga diharapkan mampu meningkatkan layanan bagi pengguna sehingga nanti diharapkan mampu maningkatkan mutu dan brand madrasah. Website layanan ini merupakan hasil diskusi antara yayasan dan guru-guru yang difasilitasi oleh peneliti.

Meningkatnya mutu dan layanan madrasah bisa menjadi sangat efektif apabila semua berita, informasi dan layanan di upload dalam website. Informasi yang dimaksud adlah segala kegiatan madrasah baik pada unit TPQ, RA, MI dan MTs di upload dalam website. Berita yang dimaksud misalnya upacara, lomba-lomba, kegiatan hardiknas, kegiatan-kegiatan keagamaan, serta prestasiprestasi yang dimiliki oleh unit pendidikan.

Apabila hal tersebut bisa di lihat oleh wali murid maka tanpa memberikan informasi langsung masyarakat sudah tahu secara detail berita-berita disekolah. Sedangkan informasi dan layanan yang dimaksud misalnya informasi penerimaan peserta didik baru (PPDB), penerimaan rapot, class metting, dan hasil Ujian nasional. Apabila semua layanan bisa dengan mudah diakses oleh orang tua wali atau masyarakat secara luas maka akan memudahkan dalam hal transparansi sekolah. Hasil yang diinginkan adanya kemajuan secara progresif secara signifikan sehingga menjadi sekolah yang memberikan manfaat bagi masyarakat.

Dari hasil sharing, diskusi dengan internal yayasan di sepakati sebuah nama hosting www.yapinasya-pati.sch.id. Nama domain yapinasya ini merupakan singkatan yayasan pendidikan islam nahdlotusy Syubban, memberikan tambahan pati merupakan identitas dari daerah dengan berbagai pertimbangan, Nama lembaga Islam sangat banyak sekali dan banyak sama persis. Setelah dicek di google banyak sekali yang sama, Contoh ada nama yang sama persis seperti di Demak yang juga sebagai lembaga pendidikan, Demikian juga ada nama yang sama persis di pati utara tetapi sebagai nama lembaga pendidikan pondok pesantren. Setelah didesain sebuah nama website yapinasya selanjutnya di adakan workshop yang di ikuti perwakilan kepala TPQ, RA, MI dan MTs Nahdlotusy Syubban pada dan ditambah admin dari masing-masing unit pendidikan pada tanggal 1 oktober 2017.

Diharapkan setiap unit pendidikan memiliki satu admin yang mampu memfollow upi segala informasi dan progress yang perlu di upload maupun 
diwebsite. Pelaksanaan workshop ini diadakan di Gedung madrasah yang di hadiri oleh Kepala sekolah dan Admin dan beberapa guru yang tertarik dalam website. Akhirnya ditunjuklah 3 admin yang mewakili MI dan MTs sedangkan RA dan TPQ di gabung menjadi 1. Dengan nama-nama admin sebagai berikut Sulastri, S.Pd, Siti Zubaedah, S.Pd dan Ani Rahmawati. Nama ketiga admin inilah yang diharapkan mampu mengelola website supaya manjadi lebih baik.

Kegiatan dampingan ini dalam bentuk workshop yang di ikuti oleh Kepala Sekolah masing-masing Unit dan admin serta Bapak Ibu Guru, dengan pemateri Bapak M. Izzatul Faqih, M.Pd seorang web master dan pakar IT dari UIN Walisongo. Selanjutnya narasumber secara detail menjelaskan pengelolaan web dan melatih secara khusus kepada admin masing-masing unit dengan didampingi kepala sekolah. Bagaimana pengelolaan web, mengedit, mengupload, mendownload, dan mendesain web yapinasya-pati.sch.id.

Dalam workshop tersebut menghasilkan admin yang siap mengoperasikan web dalam pengelolaan dan manajemen web. Terdapat tida orang admin yang mahir yaitu Sulastri, Siti Zubaedah dan Ani Rahmawati.

Setelah selesai workshop website bagi admin selanjutnya dipantau bagaimana perkembangan web-nya sehingga pengabdi melakukan evaluasi lagi ke lokasi pengabdian untuk mengetahui bagaimana follow up dari pengabdiannya. Evaluasi ini penting sebagai kontinuitas website bagi madarasah. Diharapkan website yang terbentuk tidak hanya sekedar website tapi memberikan kontributif yang sangat luas serta mampu mengupgrade madrasah menjadi madarasah yang menjadi impian masyarakat.

Setelah selesai pendesainan website dan juga admin dari masing-masing unit pendidikan mampu dan teruji mengoperasikan, mengelola website dengan baik. Hasil tersebut bisa di lihat dari gambar di bawah ini. Website yang di desain dengan nama www.yapinasya-pati.sch.id merupakan nama dari web yayasan dengan keterangan. Nama tersebut diambil dengan alasan, kata Yapinasya merupakan singkatan dari yayasan pendidikan Islam Nahdlotusy Syubban, kata Pati untuk mencari keunikan, bahwa pati itu merupakan wilayah domisili yayasan, Sch berarti sekolah atau madrasah, dan Id artinya Indonesia.

Aktivitas dari laman menu berita dan acara tertulis secara jelas siapa yang memposting berita acara. Dari postingan tersebut dapat diketahui beberapa info yang tersaji dalam tabel 1 . Hal tesebut memberikan bukti bahwa admin siap untuk mengembangankan website menjadi lebih baik serta sesuai dengan kebutuhan madrasah baik TPQ, RA, MI dan MTs Nahdlotusy Syubban. Setelah semua siap dari masing-masing unit mampu untuk melakukan pengembangan website sebagai layanan maka selanjutnya perlu pengembangan lebih lanjut yang 
dilakukan oleh admin masing-masing berkoordinasi dengan pihak kepala masing-masing unit. Sehingga di harapkan website bisa berjalan dengan baik.

Tabel 1. Sampel Postingan Admin

\begin{tabular}{|c|c|c|c|c|}
\hline Judul Postingan & Tgl & Laman & Admin & Unit \\
\hline $\begin{array}{l}\text { Peringatan hari santri } \\
\text { Yayasan }\end{array}$ & $29 / 10 / 17$ & $\begin{array}{c}\text { Berita dan } \\
\text { Acara }\end{array}$ & $\begin{array}{c}\text { Ani } \\
\text { Rahmawati }\end{array}$ & $\begin{array}{l}\text { Semua } \\
\text { Unit }\end{array}$ \\
\hline $\begin{array}{l}\text { Programme } \\
\text { International Student } \\
\text { Assesment (PISA) } 2017\end{array}$ & $22 / 10 / 17$ & $\begin{array}{c}\text { Berita dan } \\
\text { Acara }\end{array}$ & $\begin{array}{c}\text { Siti } \\
\text { Zubaedah }\end{array}$ & MTs \\
\hline $\begin{array}{l}\text { Wisuda Akbar Yayasan } \\
2017\end{array}$ & $1 / 10 / 17$ & $\begin{array}{c}\text { Berita dan } \\
\text { Acara }\end{array}$ & $\begin{array}{c}\text { Ani } \\
\text { Rahmawati }\end{array}$ & $\begin{array}{l}\text { Semua } \\
\text { Unit } \\
\text { Lembaga }\end{array}$ \\
\hline $\begin{array}{l}\text { Pelepasan anak-anak } \\
\text { kelas VI MI }\end{array}$ & $2 / 10 / 17$ & Artikel & Sulastri & MI \\
\hline
\end{tabular}

Setelah laman yapinasya-pati.sch.id diluncurkan, dalam satu minggu, diperoleh data bahwa counter pengunjung mencapai 583 pengunjung. Hal ini menandakan bahwa website yapinasya-pati.sch.id ini memiliki banyak pengunjung baik dari internal maupun ekstrenal. Banyaknya pengunjung yang tercatat dalam counter pengunjung ini mengindasikan bahwa website ini memiliki jumlah peminat yang tinggi. Walaupun seorang tidak mengetahui siapa yang mengunjungi tetapi hal ini mampu menarik minat baik baik bagi pengguna maupun pihak internal termasuk yayasan, kepala madrasah, guru dan bahkan murid. Tidak menutup kemungkinan berlaku juga kepada Alumni yayasan Nahdlotusy Syubban sarimulyo Winong.

Berdasarkan diskusi dengan kepala MI, Bapak Sumardi, S.Pd.I sangat bangga dan mendukung untuk kemajuan madrasah dan Yayasan secara umum. Harapannya juga di ikuti oleh segenap pimpinan yayasan karena mampu meningkatkan brand dan endingnya di harapkan brand dan mutu sekolah terangkat. Harapan kedepan ketika branding madrasah memiliki nilai yang baik diharapakan mampu menarik siswa sehingga madrasah menjadi besar dengan boarding school yang layak jual.

Tahap akhir berupa evaluasi dan tindak lanjut. Proses ini diupayakan dengan diskusi dan sharing dengan admin dari masing-masing unit lembaga. Evaluasi dan tindak lanjut tersebut untuk mengetahui kemampuan admin dalam mengelola website, kendala - kendala yang dialami admin dalam mengelola website dan kesanggupan admin dalam manajemen website. Dalam diksusi selama evaluasi, diketahui ternyata admin memiliki kemampuan yang cukup 
untuk mengelola website serta sanggup mengelola website. Sedangkan kendala yang dirasakan oleh admin ternyata wifi yang di miliki madrasah kadang-kadang mengalami kendala.

\section{KESIMPULAN}

Pengabdian dengan subjek Yayasan Pendidikan Islam Nahdlotusy Syubban diupayakan melalui pendekatan PAR ( partipatory action research). Dengan pendekatan PAR Subjek dampingan melakukan perubahan untuk memecahkan solusi dari problem yang dialami oleh unit pendidikan yang menjadi tanggung jawab yayasan. Problem yang dimaksud adalah lambatnya layanan dan informasi madrasah baik kepada orangtua wali, alumni, internal marasah atau bahkan masyarakat secara umum.

Dalam pengabdian ini terbagi menjadi 3 tahap yaitu mapping lokasi, tindakan dan evaluasi. Hasilnya di desainlah website yayasan www.yapinasya_pati.sch.id, dengan 3 orang admin yang mengelola website di Yayasan Nahdlotusy Syubban yang meliputi TPQ/Madin, RA, MI dan MTs Nahdlotusy Syubban yang mampu, dan sanggup mengelola website yayasan supaya lebih berkembang. Keberlangsungan website tersebut di ikuti oleh komitmen pengurus yayasan, civitas akademik madrasah dan alumni untuk selalu menjaga keberlangsungan website sebagai jasa layanan sehingan brand dan mutu madrasah semakin meningkat.

\section{DAFTAR PUSTAKA}

Kementerian pendidikan dan kebudayaan, 2005, Kamus Besar Bahasa Indonesia, Jakarta: Balai Pustaka

Agung, Leo. (2011). Aplikasi Web Database dengan Dreamwever dan PHP-MySQL. Yogyakarta: Andi.

Anwar, E.D. dkk, 2015, Revitalisasi MI Nabdlotusy Syubban dengan Pendekatan PSM (Peran Serta Masyarakat) untuk. Meningkatkan Kemandirian Sekolah, Laporan PKM ( Pengabdian Kepada masyarakat), Bantuan Diktis 2015

Heru Ruwandar, R. Arum SP, dan Helmy Fitriawan, 2012. Rancang Bangun Sistem Informasi Akademik Menggunakan PHP dan MYSQL (Studi kasus pada 
fakultas Teknik Universitas Lampung). http://www.boc.web.id/pengertianwebsite-webhosting-domainname diakses tanggal 27 mei 2018 jam 9.00

bttp:/ / www.syakirurohman.net/2014/11/pengertianl-apa-itu-javascript-manfaat-caraerja.html.

https:/ / kbbi.web.id/ Lembaga diakses tanggal 15 Mei 2017

Iswanto. 2007. Membangun Aplikasi berbasis PHP 5 dan Firebird 1.5. Yogyakarta. Penerbit ANDI

Kadir, Abdul. (2008). Dasar Pemrograman Web Dinamis Menggunakan PHP (Revisi). Yogyakarta: Andi Offset.

Kadir, Abdul. 2010. Mudab mempelajari database MySQL. Yogyakarta. Penerbit ANDI.

Luthfi, Hisyam Wahid Luthfi \& Berliana Kusuma Riasti. (2013). Sistem Informasi Perawatan dan Inventaris Laboratorium pada Smk Negeri 1 Rembang Berbasis Web. Indonesian Jurnal on Computer Science, Vol 10, No 1. 83-91.

Peraturan Pemerintah No. 19 tabun 2005 tentang Standar Nasional Pendidikan

Pio Oktaria, Yenti Puspa Sari, Mardiani, Hermawan, 2013. Rancang Bangun Sistem Informasi Akademik Berbasis web Pada Fakultas Ekonomi Universitas Muhammadiyah Palembang

Solichin, Achmad S.Kom. 2010. Pemrograman Web dengan PHP dan MySQL. Jakarta. Universitas Budi Luhur.

Sugiyono. 2012. Metode Penelitian Pendidikan: Pendekatan Kuantitatif, Kualitatif, dan RÆD. Bandung: Alfabeta.

www. wikipedia.com diakses tanggal 27 Mei 2018 jam 09.00 
